\title{
Variation in tospovirus transmission between populations of Frankliniella occidentalis (Thysanoptera: Thripidae)
}

\author{
F. van de Wetering ${ }^{1}$, M. van der Hoek ${ }^{1}$, R. Goldbach ${ }^{1}$, \\ C. Mollema ${ }^{2}$ and D. Peters ${ }^{1 *}$ \\ ${ }^{1}$ Laboratory of Virology, Wageningen Agricultural University, \\ Binnenhaven 11, 6709 PD Wageningen, The Netherlands: \\ ${ }^{2}$ Department of Research Strategy (DLO), PO Box 59, \\ 6700 AB Wageningen, The Netherlands
}

\begin{abstract}
Fourteen populations of the western flower thrips Frankliniella occidentalis Pergande, originating from different hosts and countries in Asia, Europe, North America and New Zealand, were analysed for their competency and efficiency to transmit tomato spotted wilt virus (TSWV). All populations acquired and subsequently transmitted the virus, and were thus competent to transmit. They show marked differences in their efficiency, expressed as the percentage of transmitting adults. Efficiencies varied from $18 \%$ for a F. occidentalis population from the USA (US2) to 75\% for a population from Israel (IS2). The differences between populations were not affected by the amount of virus ingested or by the host plant used. However, the tospovirus species studied and age at which the larvae acquired the virus affected the efficiency to transmit. First instar larvae of the NL3 population from The Netherlands were able to acquire tomato spotted wilt virus, whereas second instar larvae failed to do so. However, both instars of this population acquired impatiens necrotic spot virus (INSV), another tospovirus. This and tomato spotted wilt virus were both acquired by both larval stages of the populations IS2 and US2, although their ability to acquire virus decreased with their age. Hence, it is likely that, in general, both instar larvae of most $F$. occidentalis populations are competent to acquire both tospoviruses. These results show that large differences exist in the efficiency by which tomato spotted wilt is transmitted by the various F. occidentalis populations and that the ability to acquire tospovirus decreases with the age of the larvae
\end{abstract}

\section{Introduction}

Tospoviruses cause serious diseases in crops cultivated in the open field and in greenhouses throughout tropical, subtropical and temperate climate zones (German et al., 1992; Peters et al., 1996). Of all tospoviruses, tomato spotted wilt virus (TSWV) (Bunyaviridae, Tospovirus) is the most predominant one. Due to its large host range, rapid

*Author for correspondence.

Fax: +317484820

E-mail: dick.peters@medew.viro.wau.nl expansion and poor control of its vectors, this virus ranks among the top ten most economically important plant viruses (Goldbach \& Peters, 1994).

Tospoviruses are transmitted by thrips (Thysanoptera: Thripidae), minute insects approximately $1 \mathrm{~mm}$ long. In the 1930 s and 1940s, the major vector of tomato spotted wilt virus was considered to be the onion thrips, Thrips tabaci Lindeman (Thysanoptera: Thripidae) (Pittman, 1927). Diseases caused by this virus faded almost completely away in western Europe in the 1950s, probably due to effective and intensive chemical control of this species, or to changes in agricultural and horticultural practices. A renewed incidence of this virus in the 1980s has been attributed to unintentional 
Table 1. Geographical origin and host plants of the Frankliniella occidentalis populations tested for their transmission efficiency.

\begin{tabular}{llll}
\hline Population & Country & Crop & Collector \\
\hline DK & Denmark & Bean & H.F. Brødsgaard \\
FR & France & Bean & F. Leclant \\
IS1 & Israel & Strawberry & M. Klein \\
IS2 & Israel & Mango & M. Klein \\
IT & Italy & Bean & M.G. Tommasini \\
JA & Japan & Chrysanthemum & T. Murai \\
NL1 & The Netherlands & Cucumber & C. Mollema \\
NL2 & The Netherlands & Chrysanthemum & E.R van Dijken \\
NL3 & The Netherlands & Bean & I. Wijkamp \\
NL4 & The Netherlands & Tomato & P.M.J. Ramakers \\
NL5 & The Netherlands & Rose & J.J. Fransen \\
NZ & New Zealand & Egg plant & N.A. Martin \\
US1 & United States & Gloxinia & J.R. Baker \\
US2 & United States & Chrysanthemum & E.A. Shearin \\
\hline
\end{tabular}

import, rapid dispersal and increased pesticide resistance of a new effective vector, the western flower thrips Frankliniella occidentalis (Pergande) (Thysanoptera: Thripidae) (Brødsgaard, 1994; Robb et al., 1995; Wijkamp et al., 1995; Zhao et al., 1995). This thrips species was originally known as a local pest in the western part of the USA (Moulton, 1931). To date, its occurrence has been reported throughout North and Central America, Africa, Australia, Europe, the Middle East, south-east Asia and New Zealand (Brødsgaard, 1989; Anon., 1993; Dal Bó et al., 1995). The expansion of $F$. occidentalis was associated with the occurrence of another, but distinct tospovirus, impatiens necrotic spot virus (INSV), in the United States (Law \& Moyer, 1990) and Europe (de Ávila et al., 1992). To date, at least eight distinct tospovirus species have been reported (Kormelink et al., 1998), each is transmitted by one or more thrips species out of the eight known as vectors of tospoviruses (Wijkamp et al., 1995; Webb et al., 1998). Frankliniella occidentalis, one of these vectors, is one of the most efficient transmitters of tomato spotted wilt and impatiens necrotic wilt virus (Wijkamp et al., 1995).

Unfortunately, tospovirus spread can not be efficiently controlled by the pest management strategies (Todd et al., 1996; Daughtrey et al., 1997). The development of alternative and durable strategies to control tospoviruses and their vectors also depend on a better understanding of tospovirus epidemics, and hence of tospovirus-vector interactions. Although many transmission parameters have been studied, including virus propagation in F. occidentalis (Ullman et al., 1993; Wijkamp et al., 1993) after acquisition by young larvae (van de Wetering et al., 1996), information on possible differences in virus transmission efficiencies by thrips populations from different origins is lacking. Variations exist between the various $F$. occidentalis populations in their ribosomal RNA (Gillings et al., 1995), reproduction and damaged caused on cucumber plants, body size and host adaptation (de Kogel et al., 1997). The ability to acquire and transmit tospoviruses may also differ for the various $F$. occidentalis populations.

This report presents the results of a study on the adults of 14 F. occidentalis populations, collected from different hosts and regions of the world, to transmit tomato spotted wilt virus. Efficiency was analysed using two different tospoviruses after being acquired by specimens of both instars from three of the populations studied. The effects of virus source and test plant on the transmission were also compared in this study.

\section{Materials and methods \\ Origins and maintenance of thrips colonies}

Samples of the different $F$. occidentalis populations were originally collected from various crops and locations throughout the world (table 1). These samples were designated as 'populations' in this report as they did not derive from a single female or from a single male and female. Most of these populations were maintained at the Centre for Plant Breeding and Reproduction Research (CPRO-DLO) Wageningen for at least two and half years. The Dutch populations were kept for two to seven years in culture in our laboratory. They were all identified by $\mathrm{Mr}$ Vierbergen (Plant Protection Service, Wageningen) as $F$. occidentalis. Virus-free cultures were continuously reared on bean pods (Phaseolus vulgaris L. cv. Prelude) in glass jars at 27 $\pm 0.5^{\circ} \mathrm{C}$ and a16:8 h light:dark period (de Kogel et al., 1997; Peters et al.,1997). To avoid contamination with thrips from other origins, the pods were washed in water, incubated at $27 \pm 0.5^{\circ} \mathrm{C}$ for four days, and washed again to remove any hatched larvae before the pods were used in the cultures. Contamination between the populations was prevented by methods described in detail by Peters et al. (1997).

\section{Tospovirus populations and test plants}

In this study, the Brazilian tomato spotted wilt virus isolate BR-01 (de Ávila et al., 1990) and the impatiens necrotic spot virus isolate NL-07 (de Ávila et al., 1992) were used. Both viruses were maintained by thrips inoculation on Datura stramonium L. (Solanaceae) and Nicotiana benthamiana Domin. (Solanaceae) plants, respectively. To infect the larvae with virus, they were either fed on D. stramonium, Impatiens sp. (Balsaminaceae) or N. benthamiana plants infected with TSWV, or on Impatiens sp. or N. benthamiana plants infected with INSV. These plants were mechanically inoculated on the first two true leaves with extracts from thrips-inoculated plants and kept in a greenhouse at approximately $22^{\circ} \mathrm{C}(16: 8$ $\mathrm{h}$ of light:dark).

\section{Tospovirus detection by enzyme-linked immunosorbent assay} (ELISA)

The viral nucleocapsid protein $(\mathrm{N})$ content of the infected D. stramonium or Impatiens sp. leaves used as virus source, was determined with the double antibody sandwich (DAS) 

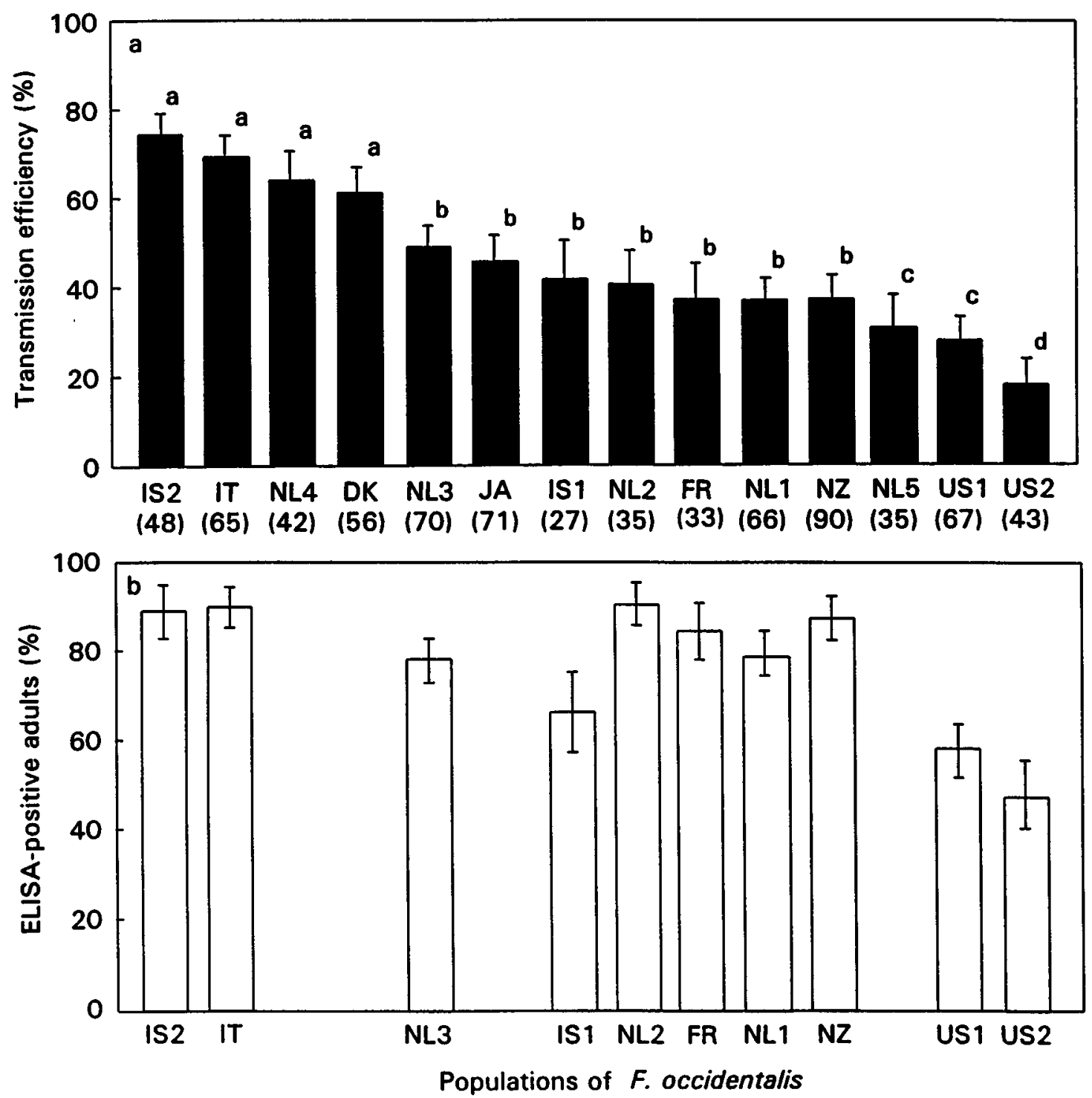

Fig.1. (a) Tomato spotted wilt virus (TSWV) transmission efficiency ( \pm s.e.), as determined by petunia leaf disk assay, and (b) enzymelinked immunosorbent assay (ELISA)-positive adult thrips after a $24 \mathrm{~h}$ acquisition access period on TSWV-infected plant material of Datura stramonium by different populations of Frankliniella occidentalis. Values in parentheses represent the number of thrips tested. Bars with a common letter are not significantly different (paired t-test, $P<0.05$ )

enzyme-linked immunosorbent assay (ELISA) (Clark \& Adams, 1977; Resende et al., 1991). Extracts were prepared by grinding of leaf disks, $5 \mathrm{~mm}$ in diameter, at a ratio 1:30 $(\mathrm{w} / \mathrm{v})$ in PBS-T $\left(140 \mathrm{mM} \mathrm{NaCl}, 1 \mathrm{mM} \mathrm{KH}_{2} \mathrm{PO}_{4}, 8 \mathrm{~mm}\right.$ $\mathrm{Na}_{2} \mathrm{HPO}_{4}, 2.5 \mathrm{mM} \mathrm{KCl}$ and $0.05 \%$ Tween-20). Extracts from non-infected plants were used as controls. Individual thrips were analysed for their TSWV-N protein content by a cocktail ELISA followed by enzyme amplification as described previously (van de Wetering et al., 1996). Polyclonal antiserum, raised against the N-protein of BR-01 and NL-07, was used in both assays (van de Wetering et al., 1996). ELISA readings were corrected for blanks read from wells containing only sample buffer in the incubation step.
Readings higher than the average non-infected controls, either from plants or thrips, plus three times their s.d., were considered to be positive, those with lower readings as negative. These readings plus their s.d. ranged from 0.045 to 0.060 for healthy plant material and from 0.019 to 0.021 for healthy thrips.

\section{Handling thrips in transmission experiments}

To obtain cohorts of equally aged larvae, fresh bean pods were placed in F. occidentalis colonies. After $24 \mathrm{~h}$, these pods were incubated at $27^{\circ} \mathrm{C}$ after removal of the thrips. The larvae, which emerged on these pods four days later, were 
collected every $4 \mathrm{~h}$ and subsequently placed on the virus source or maintained in Tashiro cages (Tashiro, 1967; Peters et al., 1997) until they were given an acquisition feeding period. These cages consisted of three plexiglass plates of $10 \mathrm{~cm}$ long, $8 \mathrm{~cm}$ wide and respectively 6,10 and $6 \mathrm{~mm}$ thick. A hole, surrounded by a rubber ring, of $35 \mathrm{~mm}$ diameter in the centre of the middle plate, is placed over the leaf material on top of blotting paper which is continuously wetted. Rubber bands, are used to tightly seal the plates together. To acquire virus, 20-30 larvae were placed in each cage on systemically infected leaf pieces with comparable Nprotein contents. The contents were determined from small disks, $5 \mathrm{~mm}$ in diameter, from the leaves to be used by ELISA. These leaves were cut into four or more pieces (approximately $2 \times 2 \mathrm{~cm}$ ) and randomly divided between the cages. Similarly sized groups of larvae were caged on non-infected plant material as blanks. After the acquisition access period, the larvae were transferred to Tashiro cages with virus free plant material of the same species as on which the virus was acquired and reared until adult emergence. Each adult was individually tested for its transmission efficiency on a leaf disk (13 $\mathrm{mm}$ in diameter) of Petunia $\times$ hybrida cv. 'Polo Blauw' in three successive inoculation access periods of $48 \mathrm{~h}$ as previously described (Wijkamp \& Peters, 1993). After each inoculation access period, the leaf disks were incubated on water for three days at $27 \pm 0.5^{\circ} \mathrm{C}$ for development of local lesions. The transmission efficiency was calculated as the percentage of infected leaf disks and statistically analysed by the paired $t$-test.

\section{Transmission of tomato spotted wilt virus by different F. occidentalis populations}

Newly hatched larvae were placed on infected $D$. stramonium leaf material for $24 \mathrm{~h}$. After this acquisition access period, the thrips completed their larval and pupal development on non-infected D. stramonium leaves. Directly after becoming adult, the thrips were individually tested for their transmission efficiency. Each adult of ten F. occidentalis populations used in these tests was sampled, stored at $-70^{\circ} \mathrm{C}$ and later assayed in cocktail-ELISA followed by enzyme amplification to determine the percentage of ELISApositive thrips. Transmission experiments and ELISA were executed in two replicates in which 27-90 adults were used per population (fig. 1). All treatments performed in each replicate were done with all populations in the same conditions and on the same day, and the larvae acquired the virus from plants infected at the same date and kept after the acquisition period on leaf material of the same age.

\section{Virus acquisition by first and second instar larvae of F. occidentalis populations}

Age effects of virus acquisition on transmission were compared between newly hatched first instar (L1) larvae, 36-h-old larvae (being a mixture of L1s and second instars (L2s)), and L2 larvae (72-h-old) of the F. occidentalis populations IS2, NL3, and US2. These thrips were placed for a 4-h acquisition access period on tomato spotted wilt or impatiens necrotic spot virus infected leaf material of $N$. benthamiana plants. Before and after this acquisition access period, the thrips were kept on virus free $D$. stramonium plant material. The transmission efficiency was calculated by the number of infected petunia leaf disks (Wijkamp \& Peters, 1993). In total, 44 to 113 thrips were used per treatment (fig. 2).

\section{Virus acquisition and transmission by F. occidentalis from and to different plant species}

Up to 4-h-old larvae of the populations IS2, NL3 and US2 were placed for $24 \mathrm{~h}$ on tomato spotted wilt virus infected leaf material of D. stramonium and Impatiens sp. The selected leaves had approximately the same virus content as determined by ELISA. After the acquisition access period, the thrips were maintained on leaves from non-infected plants of the species on which the virus was ingested. As they became adults, their ability to transmit this virus was individually tested in a $48 \mathrm{~h}$ inoculation access period on leaf disks of the species on which the larvae were maintained, and in two inoculation access periods of $48 \mathrm{~h}$ on petunia leaf disks. To randomize the effect of ageing of thrips on the transmission, they were placed in successive inoculation access periods on disks arranged in a Latin square design. Infection was demonstrated either by local lesions on petunia disks or by ELISA when disks of other plant species were used as they did not develop discernible symptoms. The transmission efficiency was expressed as the percentage of disks infected. The ELISA readings of the leaf disks infected by different $F$. occidentalis populations were compared. Leaf disks of non-infected plants of D. stramonium and Impatiens sp. plants served as controls. Results were obtained with 43, 33 and 61 adults on D. stramonium leaf disks and 20,13 and 29 adults on Impatiens sp. disks from the populations IS2, NL3 and US2, respectively.

To estimate the amount of TSWV-N protein ingested, approximately 18 larvae of populations IS2, NL3 and US2 were randomly collected after an $8 \mathrm{~h}$ acquisition access period and stored at $-70^{\circ} \mathrm{C}$ prior to ELISA. The ELISA readings were analysed using Duncan's multiple range test with a STATGRAPHICS 6.0 PLUS computer program (Schulman, 1992; Rijpkema, 1993).

\section{Results}

Variation in TSWV transmission efficiencies between different F. occidentalis populations

The efficiency of 14 populations of F. occidentalis (table 1), competent to transmit tomato spotted wilt virus, was compared (fig. 1a) using the paired t-test. Forty-eight percent of the adults of the reference strain NL3 transmitted this virus. Approximately similar, but slightly lower efficiencies, although not significantly different, were found for the populations collected in France (FR), Israel (IS1), Japan (JA) and New Zealand (NZ), and for the two other Dutch populations (NL1 and NL2). The American population US1 and a Dutch population (NL5) transmitted the virus at significantly lower efficiencies than the reference population NL3. The American population (US2) was a significantly poor transmitter. In contrast, the populations from Israel (IS2), Denmark (DK), Italy (IT) and The Netherlands (NL4) transmitted tomato spotted wilt virus with significantly higher efficiencies than NL3 (fig. 1a). IS2 was, with an efficiency of $75 \%$, the most efficient transmitting population. These results indicated that the transmission efficiency did not only differ between thrips populations from different 
geographic regions and hosts, but also between populations collected from the same region, i.e. Israel (IS1 and IS2) and the Netherlands (NL3, NL4 and NL5).

The percentage of ELISA-positive adults was always a factor of 1.2 to 2.7 higher than the number of transmitting thrips (fig. 1b). The transmission efficiency was weakly correlated $(\mathrm{R}=0.7)$ with the virus content of the thrips. These results showed that transmission efficiency by adult thrips was the most useful parameter used to characterize $F$. occidentalis populations in tospovirus transmission instead of the time-consuming determination of percentage of ELISApositive adults.
Acquisition of two different tospoviruses by first and second instar larvae of three F. occidentalis populations

Previous studies showed that only the first instar larvae of the F. occidentalis population NL3 could acquire tomato spotted wilt virus (van de Wetering et al., 1996). To test whether this observation was a general phenomenon of $F$. occidentalis, the ability to acquire this virus was also determined for the first and second instar larvae of populations IS2 and US2. These populations were chosen because they differed strongly in their efficiency to transmit this virus (fig. 1a).

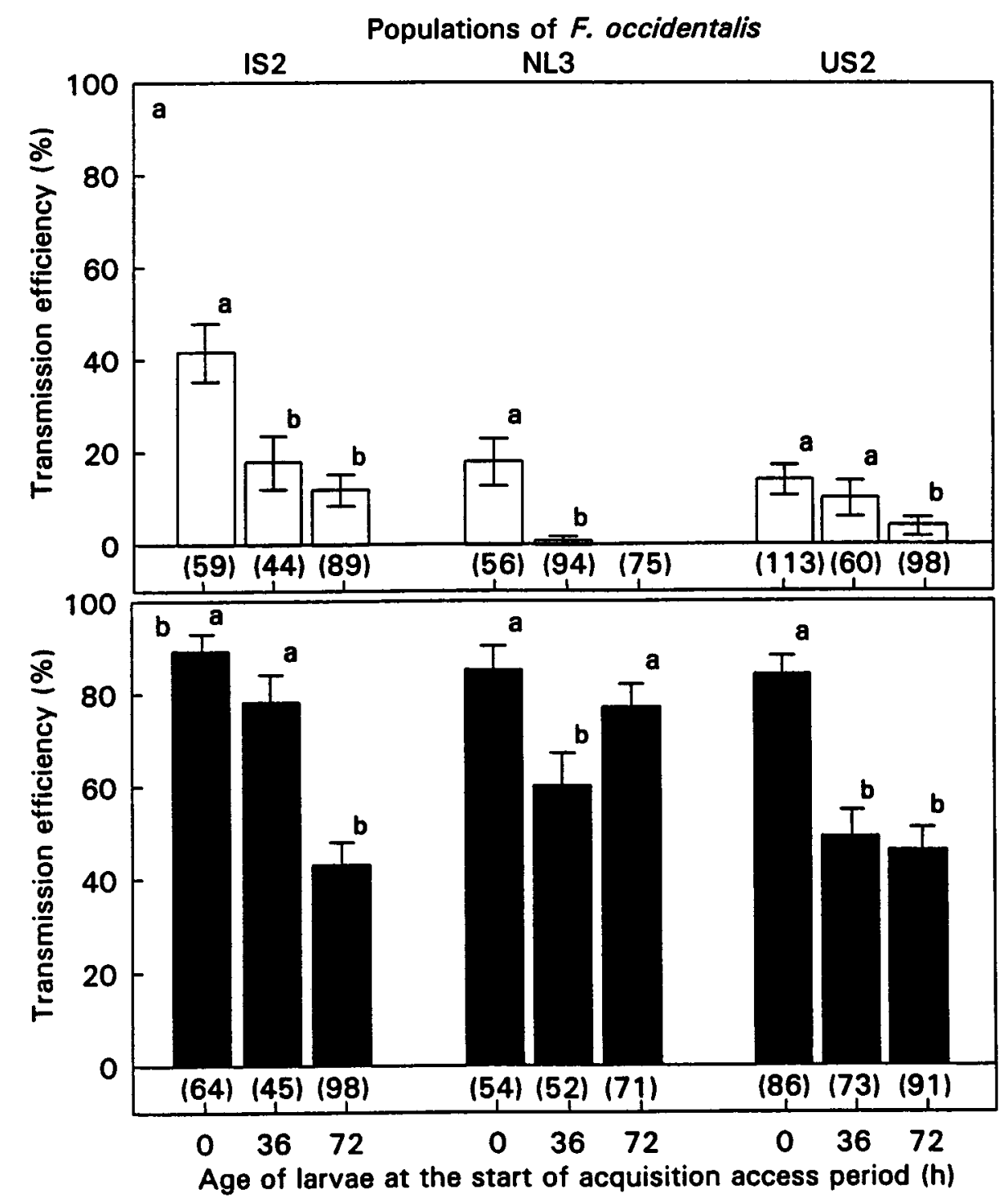

Fig. 2. (a) Tomato spotted wilt virus and (b) impatiens necrotic spot virus transmission after a $4 \mathrm{~h}$ acquisition access period by $0-4$-h-old larvae (L1), $36 \mathrm{~h}(\mathrm{~L} 1+\mathrm{L} 2)$ and 72-h-old larvae (L2) of Frankliniella occidentalis populations from Israel (IS2), The Netherlands (NL3) and United States (US2) (means \pm s.e.). Values in parentheses represent the number of thrips tested. Bars with a common letter are not significantly different (paired t-test, $P<0.05$ ). 
Table 2. Ingestion of tomato spotted wilt virus (TSWV) by newly hatched first instar larvae of three populations of Frankliniella occidentalis after $8 \mathrm{~h}$ exposure to virus infected Datura stramonium or Impatiens sp. plants.

\begin{tabular}{|c|c|c|c|c|c|c|}
\hline \multirow{3}{*}{$\begin{array}{l}\text { Populations of } \\
\text { F. occidentalis }\end{array}$} & \multicolumn{6}{|c|}{ Plant species } \\
\hline & \multicolumn{3}{|c|}{ Datura stramonium } & \multicolumn{3}{|c|}{ Impatiens sp. } \\
\hline & $n^{1}$ & $\begin{array}{l}\text { ELISA } \\
\text { positive }^{2}\end{array}$ & $\begin{array}{l}\text { ELISA } \\
\text { readings }^{3}\end{array}$ & $n^{1}$ & $\begin{array}{l}\text { ELISA } \\
\text { positive }^{2}\end{array}$ & $\begin{array}{l}\text { ELISA } \\
\text { readings }{ }^{3}\end{array}$ \\
\hline IS2 & 18 & 18 & $0.126 \pm 0.044^{4 a}$ & 18 & 15 & $0.093 \pm 0.022^{4 a}$ \\
\hline NL3 & 15 & 14 & $0.146 \pm 0.023^{\mathrm{a}}$ & 17 & 7 & $0.072 \pm 0.019^{a}$ \\
\hline US2 & 17 & 17 & $0.112 \pm 0.019^{a}$ & 19 & 9 & $0.031 \pm 0.002^{\mathrm{a}}$ \\
\hline
\end{tabular}

${ }^{1}$ Number of thrips tested by ELISA; ${ }^{2}$ number of thrips showing a virus positive reaction in ELISA at $490 \mathrm{~nm} ;{ }^{3}$ ELISA readings, at $405 \mathrm{~nm}$, denoted as the average \pm s.e.; ${ }^{4}$ ELISA readings within a column followed by the same letter are not significantly different according to Duncan's multiple range test $(P<0.05)$.

Adults of the NL3 population failed to transmit when the virus was offered to 72-h-old second instars (fig. 2a), confirming earlier results (van de Wetering et al., 1996). In the present study, ingestion of virus by 72-h-old second instars of the populations IS2 and US2 resulted in a transmission efficiency of 12 and $4 \%$ by adults, respectively, showing that transmission efficiencies were considerably lower than when first instar larvae ingested this virus.

To study whether tospovirus acquisition like that of tomato spotted wilt virus is restricted to first instar larvae, another species, impatiens necrotic spot virus (INSV), was included in these experiments. This virus was significantly $(P>0.05)$ more efficiently transmitted by $F$. occidentalis than tomato spotted wilt virus (TSWV) (fig. 2b), confirming previous studies (Wijkamp \& Peters, 1993; Wijkamp et al., 1995). With both viruses, transmission efficiencies decreased for the three populations tested with the age at which the larvae ingested virus. Adults of all three populations transmitted impatiens necrotic spot virus at efficiencies of approximately $85 \%$, after ingesting the virus as newly hatched larvae (fig. 2b). The 72-h-old second instars of all three populations were able to acquire this virus, including the NL3 population, and as adults transmitted this virus with efficiencies ranging between $43 \%$ (IS2) and 77\% (NL3).

Ingestion of tomato spotted wilt virus by first instar larvae of the IS2, NL3 and US2 populations was analysed after they had fed for $8 \mathrm{~h}$ on infected $D$. stramonium and Impatiens sp. leaf material (table 2). The results showed that ingestion of this virus did not differ significantly for the three $F$. occidentalis populations tested, according to Duncan's multiple range test $(P<0.05)$.

\section{Effect of plant species on tomato spotted wilt virus acquisition and transmission}

Datura stramonium and Impatiens sp. plants were used to test possible host plant effects on the acquisition and transmission of tomato spotted wilt virus by the $F$. occidentalis populations IS2, NL3 and US2. Each population transmitted the virus at an almost similar efficiency to the leaf disks of petunia, D. stramonium and Impatiens sp. $(P<0.05$; fig. 3). Only, a significant difference (paired t-test; $P>0.05)$ was found in the transmission of tomato spotted wilt virus to D. stramonium and petunia leaf disks by US2 adults (fig. 3). Hence, it can be concluded that the efficiency at which the different $F$. occidentalis populations transmit tospovirus is not affected by the plant species used. In addition, the development of first instar larvae to adult did not differ between these three populations when they were reared on D. stramonium or Impatiens sp. plants (results not shown). The ELISA readings of the leaf disks infected by viruliferous adults of the populations IS2, NL3, and US2, however, differed considerably (Duncan's multiple range test, $\mathrm{P}>0.05$; table 3 ). Leaf disks of $D$. stramonium inoculated by viruliferous adults of IS2 had considerably higher ELISA readings than those inoculated by NL3 adults. In addition, infected disks of D. stramonium and Impatiens sp. by thrips of US2 population had significantly lower ELISA readings, implying a lower virus content, than disks infected by adults of the IS2 and NL3 population.

\section{Discussion}

These studies demonstrated that F. occidentalis populations, collected at fourteen locations from different crops, were competent to transmit tomato spotted wilt virus. However, the transmission efficiency, expressed as the percentage of transmitting adults of these populations, ranged from $18 \%$ (population US2) to $75 \%$ (population IS2) (figs 1a, 2a,b). The constant efficiency by which the NL3 reference population transmitted TSWV over a period of six years (Wijkamp \& Peters, 1993; Wijkamp et al., 1993, 1995; van de Wetering et al., 1996), shows that the tospovirus transmission efficiency is a stable character. Since the other

Table 3. The tomato spotted wilt virus content of Datura stramonium and Impatiens sp. leaf disks as determined by enzyme-linked immunosorbent assay (ELISA) after inoculation by adults of three Frankliniella occidentalis populations.

\begin{tabular}{llc}
\hline $\begin{array}{c}\text { Populations of } \\
\text { F. occidentalis }\end{array}$ & \multicolumn{2}{c}{ Plant species } \\
\cline { 2 - 3 } & Datura stramonium & Impatiens sp. \\
\hline IS2 & $(29)^{1} 0.658 \pm 0.087^{2 \mathrm{a}}$ & $(15)^{1} 1.108 \pm 0.061^{2 \mathrm{a}}$ \\
NL3 & $(18) 0.384 \pm 0.091^{\mathrm{b}}$ & (6) $1.035 \pm 0.071^{\mathrm{a}}$ \\
US2 & $(19) 0.061 \pm 0.008^{\mathrm{c}}$ & (8) $0.698 \pm 0.113^{\mathrm{b}}$ \\
\hline
\end{tabular}

${ }^{1}$ Number of disks tested is indicated in parentheses; ${ }^{2}$ ELISA readings at $405 \mathrm{~nm}$ denoted as the average \pm s.e. Readings within a column followed by the same letter are not significantly different according to Duncan's multiple range test $(P<0.05)$. 


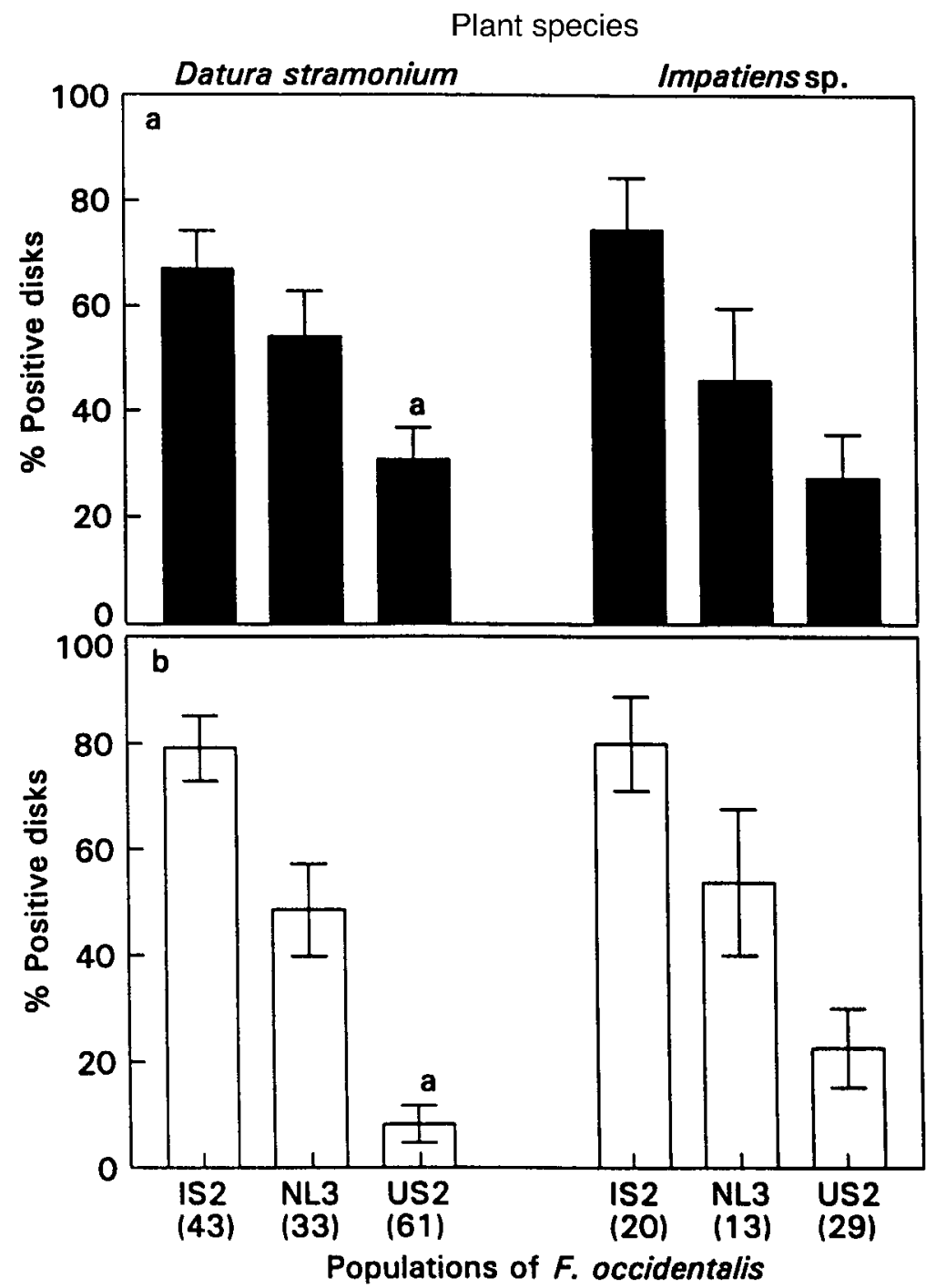

Fig. 3. Tomato spotted wilt virus transmission efficiency ( \pm s.e.) after a 24 h-acquisition access period on TSWV-infected plant material of Datura stramonium or Impatiens sp. by different populations of Frankliniella occidentalis. After the acquisition access period, the thrips were reared on virus free leaf material of the same host species. Adult thrips were tested on the disks from the plant species on which they acquired TSWV (a) or on petunia leaf disks (b). Values in parentheses represent the number of thrips tested. The only significant difference between transmission to test plants is indicated with an ' $a$ ' (paired $t$-test, $P<0.05$ ).

populations were reared under identical conditions for at least two-and-a-half years on bean pods, the transmission efficiencies found may reflect their original efficiencies. The different efficiencies are likely to be the result of a different development at the various locations.

As different $F$. occidentalis populations transmit tomato spotted wilt virus with distinct efficiencies, the question arises whether we can denote some of these populations as different 'biotypes'. Broadly speaking, the term biotype is an intraspecific category for a biological attribute, which refers to insect populations of similar genetic composition (Saxena \& Barrion, 1987). Biotypes can be classified in, e.g. aggressiveness towards resistant or susceptible varieties of crop plants and/or disease vector capabilities, like the transmission ability of tospoviruses. According to the results described in this paper, we might classify some F. occidentalis populations, which transmit tospovirus with dissimilar efficiencies, as different biotypes. Examples of this are the populations IS2, NL3 and US2. Various F. occidentalis populations, used in this study, were analysed by de Kogel et al. (1997) for their performance on cucumber accessions with different levels of resistance. They concluded that the reproduction rate of each population could be used as a criterion for differentiating $F$. occidentalis populations. 
Although these authors considered the NZ and NL1 populations as quite distinct, they did not significantly differ in TSWV transmission (fig. 1a). Future studies on the populations, including genetic analysis, are needed to describe the inter-population variation in tospovirus transmission as biotypic variation. Several studies on biotypic variation in insect species have been reported in relation to the transmission of other circulative plant viruses (Sylvester, 1980). Detailed studies with geminiviruses, transmitted by Bemisia tabaci (Gennadius) (Hemiptera: Aleyrodidae) showed that differences in transmission efficiency and virus specificity were mostly associated with differences in the epitope profiles of their coat proteins (McGrath \& Harrison, 1995). Likewise, differences between F. occidentalis populations in transmitting two tospoviruses (fig. 2a,b) might be associated with distinct structural features of the surface (glyco)proteins of tospoviruses.

Bedford et al. (1994) showed that differences in geminivirus transmission by distinct biotypes of the whitefly, B. tabaci (Bedford et al., 1992, 1993; Brown et al., 1992; Byrne \& Devonshire, 1993; Perring et al., 1993a), which are also considered to be different species (Bartlett \& Gawell, 1993; Bedford et al., 1993; Campbell et al., 1993; Perring et al., 1993a, b), were due to differences in virus distribution in the plant and feeding (ingestion) behaviour of the whiteflies. Since studies in this paper were executed with virus sources that contained similar virus contents and pieces of these leaves randomly divided between the Tashiro cages, the variation found in transmission efficiency between the different $F$. occidentalis populations cannot be attributed to differences in virus distribution or concentration. Also, the amount of tomato spotted wilt virus ingested by different $F$. occidentalis populations was comparable (table 2), ruling out an ingestion effect on the obtained transmission variation.

Differences in transmission efficiencies by F. occidentalis populations were greatly influenced by the age of larvae when feeding on infected material, and by the tospovirus species used (fig. 2a,b). First and second instar larvae of the F. occidentalis populations IS2 and US2 acquired both tomato spotted wilt virus as well as impatiens necrotic spot virus. Likewise, the latter virus was also transmitted when ingested by second instar larvae of the NL3 population, whereas these instars failed to acquire tomato spotted wilt virus. It can, therefore, be concluded that the ability of instars to acquire tospovirus depends on both the $F$. occidentalis population and the tospovirus species used.

The dissimilarities in acquisition of these viruses by the second instar larvae of the NL3 population may be explained for example by the presence of different receptors for both tospovirus species in this thrips species. However, variation in the transmission efficiencies may also be due to dissimilar midgut and salivary gland properties as shown for different populations of Thrips tabaci, affecting the replication rate of tospoviruses and their translocation in thrips (Nagata et al., 1999). Differences in the midgut receptors, the activity of digestive enzymes in the gut affecting the infectivity of the virus, and dissemination barriers are other factors which can be involved in regulating the acquisition and release of the virus by and from the gut cells. At the level of salivary glands, a barrier may exist in the infection of the salivary glands. Differences in the replication rate in these glands and release of virus in the saliva may be other factors affecting the transmission as described for other plant viruses, replicating in their vectors
(Ammar, 1994). The study presented here does not allow discrimination between any of these factors.

Transmission of tomato spotted wilt virus by F. occidentalis populations was not affected by the plant species used as virus source and test plants, as shown for $D$. stramonium and Impatiens sp. (fig. 3a,b). However, the virus content in leaf disks of these species infected by viruliferous thrips differed. The disks infected by viruliferous IS2 adults, the most efficient transmitter, contained the highest amounts of virus, whereas considerably lower amounts were found in leaf disks infected by the most incompetent transmitter, US2 (table 3). These data suggest that the different F. occidentalis populations inject different amounts of virus into disks, resulting in different virus contents. Although not very likely, it cannot be ruled out that selection might occur during the virus multiplication in the vector, resulting in variants with different replication abilities in plants. Future research has to verify whether whole plants, as found for leaf disks, are also poorly infected by the F. occidentalis population US2, and efficiently by IS2.

In view of the distinct differences in tospovirus transmission efficiencies between $F$. occidentalis populations, improved understanding of tospovirus-thrips interactions needs detailed analysis not only at the organism but also at the population level. Also, general conclusions on tospovirus spread should also be based on the dynamics of these vector populations, to circumvent inaccurate statements. To date, tospovirus control methods are focused on early detection of tospovirus and thrips vectors, and on the prevention and elimination of virus introduction and spread in a crop. The variation in tospovirus transmission by different populations of one thrips species makes prediction of virus spread more difficult. In our view, the development of the integrated tospovirus control strategies should focus on the more efficient vector populations.

\section{Acknowledgements}

This research was financed by fellowship No. ABI22.2704 of the Foundation of Dutch Technology of The Netherlands Organisation for Scientific Research. We thank Novartis BV, Enkhuizen, The Netherlands, for supplying us with Petunia $\times$ hybrida cv. 'Polo Blauw' seeds. We also like to thank Dr M. Klein, Israel, for his interest and useful discussions during the experiments. We are most grateful to all researchers who supplied us samples of different $F$. occidentalis populations (table 1), and to Dr W.J. de Kogel, The Netherlands, for rearing and maintaining them.

\section{References}

Anon. (1993) Frankliniella occidentalis (Pergande). Distribution maps of pests, no. 538. Institute of Entomology, $C A B$ International.

Ammar, E.D. (1994) Propagative transmission of plant and animal viruses by insects: factors affecting vector specificity and competence. Advanced Diseases in Vector Research $\mathbf{1 0}$ 289-331.

Bartlett, A.C. \& Gawell, N.J. (1993) Determining whitefly species. Science 261, 1333-1334.

Bedford, I.D., Briddon, R.W., Jones, P., Alkaff, N. \& Markham, P.G. (1992) Bemisia tabaci - biotype characterisation and the threat of this whitefly species to agriculture. Brighton Crop Protection Conference - Pests and Diseases 3, 1235-1240. 
Bedford, I.D., Briddon, R.W., Markham, P.G., Brown, J.K. \& Rosell, R.C. (1993) A new species of Bemisia or biotype of Bemisia tabaci (Genn.) as a future pest of European agriculture. Plant Health and the European Single Market Brighton Crop Protection Conference Monograph 54, 381-386.

Bedford, I.D., Briddon, R.W., Brown, J.K., Rosell, R.C. \& Markham, P.G. (1994) Geminivirus transmission and biological characterisation of Bemisia tabaci (Gennadius) biotypes from different geographic regions. Annals of Applied Biology 125, 311-325.

Brødsgaard, H.F. (1989) Frankliniella occidentalis (Thysanoptera: Thripidae) - a new pest in Danish greenhouses. A review. Tidsskrift foer Planteavl 93, 83-91.

Brødsgaard, H.F. (1994) Insecticide resistance in European and African strains of western flower thrips (Thysanoptera: Thripidae) tested in a new residue-on-glass test. Journal of Economic Entomology 87, 1141-1146.

Brown, J.K., Coats, S.A., Bedford, I.D., Markham, P.G. \& Bird, J. (1992) Biotypical characterisation of Bemisia tabaci isolates based on esterase profiles, DNA fingerprinting, virus transmission and bioassays to key host plant species. Phytopathology 82, 1104.

Byrne, F.J. \& Devonshire, A.L. (1993) Insensitive acetylphism in susceptible and resistant isolates of the tobacco whitefly Bemisia tabaci (Genn.). Pesticide Physiology 45, 34-42.

Campbell, B.C., Duffus, J.E. \& Baumann, P. (1993) Determining whitefly species. Science 261, 1333.

Clark, M.F. \& Adams, A.N. (1977) Characteristics of the microplate method of enzyme-linked immunosorbent assay for the detection of plant viruses. Journal of General Virology 34, 475-483.

Dal Bó, E., Ronco, L., Alippi, A.M. \& Fernández, R. (1995) Tomato spotted wilt virus on chrysanthemum in Argentina. Plant Disease 79, 538

Daughtrey, M.L., Jones, R.K., Moyer, J.W., Daub, M.E. \& Baker, J.R. (1997) Tospoviruses strike the greenhouse industry, INSV has become a major pathogen on flower crops. Plant Disease 81, 1220-1230.

de Ávila, A.C., Huguenot, C., Resende, R. de O., Kitajima, E.W., Goldbach, R.W. \& Peters, D. (1990) Serological differentiation of 20 isolates of tomato spotted wilt virus. Journal of General Virology 71, 2801-2807.

de Ávila, A.C., De Haan, P., Kormelink, R., Resende, R. de O. Goldbach, R.W. \& Peters, D. (1992) Characterization of a distinct isolate of tomato spotted wilt virus (TSWV) from Impatiens sp. in the Netherlands. Journal of Phytopathology 134, 133-151.

de Kogel, W.J., van der Hoek, M. \& Mollema, C. (1997) Variation in performance of western flower thrips populations on susceptible and partially resistant cucumber. Entomologia Experimentalis et Applicata 83, 73-80.

German, T.L., Ullman, D.E. \& Moyer, J.W . (1992) Tospoviruses: diagnosis, molecular biology, phylogeny, and vector relationships. Annual Review of Phytopathology 30, 315-348.

Gillings, M.R., Rae, D., Herron, G.A. \& Beattie, G.A.C. (1995) Tracking thrips populations using DNA-based methods. pp. 97-103 in Proceedings 1995 Australia and New Zealand Thrips Workshop: Methods, Biology, Ecology and Management.

Goldbach, R. \& Peters, D. (1994) Possible causes of the emergence of tospovirus diseases. Seminars of Virology $\mathbf{5}$, 113-120.

Kormelink, R., Peters, D. \& Goldbach, R. (1998) Tospovirus genus. Descriptions of Plant Viruses, No. 363, 11 pp.
Law, M.D. \& Moyer, J.W. (1990) A tomato spotted wilt-like virus with serologically distinct $\mathrm{N}$ protein. Journal of General Virology 73, 2125-2128.

McGrath, P.F. \& Harrison, P.D. (1995) Transmission of tomato leaf curl geminiviruses by Bemisia tabaci: effects of virus isolate and biotype. Annals of Applied Biology 126, 307-316.

Moulton, D. (1931) Western Thysanoptera of economic importance. Journal of Economic Entomology 24, 1031-1036.

Nagata, T., Inoue-Nagata, A.K., Smid, H.M., Goldbach, R. \& Peters, D. (1999) Tissue tropism related to vector competence of Frankliniella occidentalis for tomato spotted wilt tospovirus. Journal of General Virology 80, 507-515.

Perring, T.M., Cooper, A.D., Rodriguez, R.J., Farrar, C.A. \& Bellows, T.S. (1993a) Identification of a whitefly species by genomic and behavioral studies. Science 259, 74-77.

Perring, T.M., Farrar, C.A., Cooper, A.D. \& Bellows, T.S. (1993b) Determining whitefly species. Science 261, 1334-1335.

Peters, D., Wijkamp, I., van de Wetering, F. \& Goldbach, R. (1996) Vector relations in the transmission and epidemiology of tospoviruses. Acta Horticulturae 431, 29-43.

Peters, D., Loomans, A., Nagata, T., Wijkamp, I. \& van de Wetering, F. (1997) Methods to rear and maintain thrips in tospovirus transmission studies. pp. 152-159 in Proceedings 1997 Invertebrate in Captivity Conference, July 31-August 3, 1997, Tuscon, Arizona.

Pittman, H.A. (1927) Spotted wilt of tomatoes. Journal of the Australian Council for Science and Industrial Research 1, 74-77.

Resende, R. de O., de Ávila, A.C., Goldbach, R.W. \& Peters, D. (1991) Comparison of polyclonal antisera in the detection of tomato spotted wilt virus using double antibody sandwich and cocktail ELISA. Journal of Phytopathology 132, 46-56.

Rijpkema, J.J.M. (1993) Statistiek met Statgraphics. 271 pp. Schoonhoven, the Netherlands, Academic Service.

Robb, K.L., Newman, J., Virzi, J.K. \& Parrella, M.P. (1995) Insecticide resistance in the western flower thrips. pp. 341-346 in Parker, B.L., Skinner, M. \& Lewis, T. (Eds) Thrips biology and management. New York, Plenum Press.

Saxena, R.C. \& Barrion, A.A. (1987) Biotypes of insect pests of agricultural crops. Insect Science and its Application 8, 453-458.

Schulman, R.S. (1992) Statistics in plain English with computer applications. 483 pp. New York, Chapman and Hall.

Sylvester, E.S. (1980) Circulative and propagative virus transmission by aphids. Annual Review of Entomology 25, 257-286.

Tashiro, H. (1967) Selfwatering acrylic cages for confining insects and mites and detached leaves. Journal of Economical Entomology 60, 354-356.

Todd, J.W., Culbreath, A.K. \& Brown, S.L. (1996) Dynamics of vector populations and progress of tomato spotted wilt disease relative to insecticide use in peanuts. Acta Horticulturae 431, 483-490.

Ullman, D.E., German, T.L., Sherwood, J.L., Westcot, D.M. \& Cantone, F.A. (1993) Tospovirus replication in insect vector cells: immunocytochemical evidence that the nonstructural protein encoded by the S RNA of tomato spotted wilt tospovirus is present in thrips vector cells. Phytopathology 83, 456-463.

van de Wetering, F., Goldbach, R. \& Peters, D. (1996) Tomato spotted wilt tospovirus ingestion by first instar larvae of Frankliniella occidentalis is a prerequisite for transmission. Phytopathology 86, 900-905. 
Webb, S., Tsai, J. \& Mitchell, F. (1998) Bionomics of Frankliniella bispinosa and its transmission of tomato spotted wilt virus. p. 67 in Peters, D. \& Goldbach, R. (Eds) Recent progress in tospovirus and thrips research. Wageningen, the Netherlands.

Wijkamp, I. \& Peters, D. (1993) Determination of the median latent period of two tospoviruses in Frankliniella occidentalis, using a novel leaf disk assay. Phytopathology 83, 986-991.

Wijkamp, I., Van Lent, J., Kormelink, R., Goldbach, R. \& Peters, D. (1993) Multiplication of tomato spotted wilt virus in its insect vector, Frankliniella occidentalis. Journal of General Virology 74, 341-349.
Wijkamp, I., Almarza, N., Goldbach, R. \& Peters, D. (1995) Distinct levels of specificity in thrips transmission of tospoviruses. Phytopathology 85, 1069-1074.

Zhao G., Liu, W., Brown, J.M. \& Knowles, C.O. (1995) Insecticide resistance in field and laboratory strains of western flower thrips (Thysanoptera: Thripidae). Journal of Economic Entomology 88, 1164-1170.

(Accepted 24 September 1999) (c) CAB International, 1999 